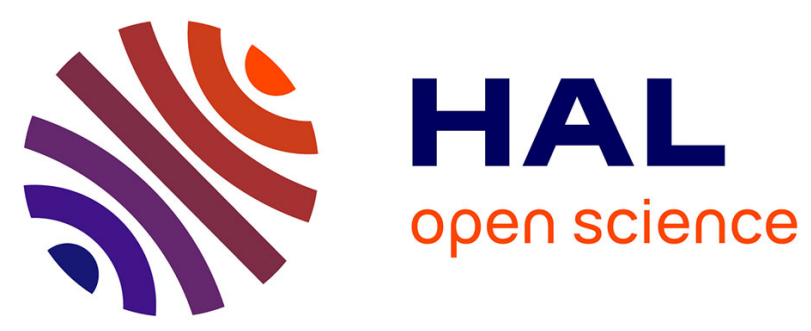

\title{
Surface modification of carbonaceous materials by fluorinated gases and use as anode in lithium-ion battery
}

Henri Groult, Tsuyoshi Nakajima, Laurent Perrigaud, Fabienne Warmont, Yoshimi Ohzawa, Rita Baddour-Hadjean, A. Tressaud, Christian M. Julien

\section{- To cite this version:}

Henri Groult, Tsuyoshi Nakajima, Laurent Perrigaud, Fabienne Warmont, Yoshimi Ohzawa, et al.. Surface modification of carbonaceous materials by fluorinated gases and use as anode in lithium-ion battery. ECS Transactions, 2007, 3 (36), pp.167-176. 10.1149/1.2795118 . hal-00165334

\author{
HAL Id: hal-00165334 \\ https://hal.science/hal-00165334
}

Submitted on 29 Oct 2021

HAL is a multi-disciplinary open access archive for the deposit and dissemination of scientific research documents, whether they are published or not. The documents may come from teaching and research institutions in France or abroad, or from public or private research centers.
L'archive ouverte pluridisciplinaire HAL, est destinée au dépôt et à la diffusion de documents scientifiques de niveau recherche, publiés ou non, émanant des établissements d'enseignement et de recherche français ou étrangers, des laboratoires publics ou privés. 


\title{
Surface Modification of Carbonaceous Materials by Fluorinated Gases and Use as Anode in Lithium-Ion Battery
}

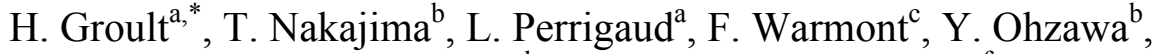 \\ R. Baddour-Hadjean ${ }^{\text {d }}$ A. Tressaud ${ }^{\text {e }}$, C.M. Julien ${ }^{\mathrm{f}}$ \\ ${ }^{a}$ Laboratoire LI2C, Université P. \& M. Curie-Paris6, UMR 7612, 4 place Jussieu, Paris, \\ F-75005 France \\ ${ }^{b}$ Department of Applied Chemistry, Aichi Institute of Technology, Yakusa-cho, \\ Toyota-shi 470-0392, Japan \\ ${ }^{\mathrm{c}} \mathrm{CRMD}, 1 \mathrm{~b}$ rue de la Férollerie, 45071 Orléans Cedex 2, France \\ ${ }^{\mathrm{d}}$ LADIR, Institut des Sciences Chimiques Seine Amont, UMR 7075, 94320 Thiais, \\ France \\ ${ }^{\mathrm{e}}$ ICMCB-CNRS, 87 Ave du Dr. A. Schweitzer, 3608 Pessac Cedex, France \\ ${ }^{\mathrm{f}}$ Institut des Nano-Sciences de Paris, UMR 7588, Université P. \& M. Curie-Paris6, \\ Campus Boucicaut, 140 rue de Lourmel, Paris, F-75015 France \\ *Corresponding author; Email: groult@,ccr.jussieu.fr; Fax: +33 144273856
}

The electrochemical performances of raw and surface-fluorinated graphite powders used as anode in Li-ion battery have been studied. The fluorination obtained from $\mathrm{F}_{2}$ gas mainly concerns the surface of the particles for $\mathrm{T}_{\mathrm{F}_{2}} \leq 300{ }^{\circ} \mathrm{C}$. For higher temperature, important modifications of the bulk structure were observed. When they are used as anode in Li-ion battery, fluorinated graphite powders exhibit better electrochemical performances than raw graphite notably due to an increase of the surface area and surface defects which allow the storage of a higher amount of lithium into the host lattice. These results have been confirmed by impedance measurements performed in delithiated state: a drastic decrease of both the charge transfer resistance and the resistance related to the SEI layer was observed for $\mathrm{T}_{\mathrm{F}_{2}} \leq 300^{\circ} \mathrm{C}$.

\section{Introduction}

In the frame of rechargeable lithium-ion batteries, lithiated graphite are widely used instead of metallic lithium as negative electrode (1-13) to avoid growth of metallic Li dendrite usually observed upon charge-discharge cycles with a metallic lithium anode. Owing to its lamellar structure, Li cations can be easily inserted and deinserted between carbon sheets of graphite. The maximum lithium content is one lithium guest atom per six carbon host atoms, giving rise to a composition of $\mathrm{LiC}_{6}$ and the theoretical specific capacity of $372 \mathrm{mAh} / \mathrm{g}$. However, the electrochemical lithium insertion/deinsertion process is characterized by an irreversible reaction occurring during the initial discharge procedure, i.e. during the first insertion of lithium cations into the host structure, which results in the formation of a passivating layer called solid electrolyte interface (SEI). Through this surface film, lithium ion is de-solvated and inserted into graphite without any degradation of the host lattice structure.

The chemical composition of the surface of the starting graphite material has a strong influence on the electrochemical performances of the graphite anode, notably on the value of the irreversible capacity. For example, the surface oxygen species are well 
known to have a significant effect on the reaction kinetics and capacity values (14-16). Heating of carbon fibers up to $1000{ }^{\circ} \mathrm{C}$ under vacuum is a suitable technique to enhance the electrochemical performances of graphite anode by reducing the influence of the oxygen species. Additives dissolved into the electrolyte are also suitable to be effective: for instance the positive influence of $\mathrm{HF}, \mathrm{CO}_{2}$, vinylene carbonate or $\mathrm{Na}^{+}$has been reported (17-21). These additives partially suppress the initial irreversibility and improve cycle life of the batteries. The modification of the graphite surface by metal or metal oxide coating (22-25) or carbon coating (26-31) is also another way proposed in the literature to enhance the electrochemical performances of graphite anode.

For surface treatment, fluorine (32) and fluorinated gases such as $\mathrm{NF}_{3}, \mathrm{ClF}_{3} \ldots$ have been widely used in various industrial fields. For instance, $\mathrm{NF}_{3}$ is used for semiconductors etching, $\mathrm{ClF}_{3}$ to clean semiconductor fabrication vessels in the computer chip industry, $\mathrm{F}_{2}-\mathrm{N}_{2}$ mixture to strengthen the surface properties of plastics (impermeability, chemical resistance, barrier effect, etc.). $F_{2}$ or plasma fluorination using $\mathrm{CF}_{4}$ gas reacts with carbonaceous materials to form semi-ionic or covalent C-F (9,33-41): fluorination of graphite at $\mathrm{T}>350{ }^{\circ} \mathrm{C}$ leads to the formation of graphite fluorides $(\mathrm{CF})_{\mathrm{n}}$ and $\left(\mathrm{C}_{2} \mathrm{~F}\right)_{\mathrm{n}}$ having covalent $\mathrm{C}-\mathrm{F}$ bonds, which are commercially used in primary lithium batteries. Surface fluorination by $\mathrm{F}_{2}$ or radio-frequency plasma fluorination using $\mathrm{CF}_{4}$ have been recently proposed to improve the performances of graphite powders $(9,33,42-$ 44) or petroleum cokes (45-47). In that case, the reaction time must be short (few minutes) only to modify the surface properties of the graphite.

In the present study, the influence of the nature of the fluorinated gases on the modifications of the structural properties of natural graphite powder will be presented. It will be shown that such a fluorination with elemental fluorine modifies the surface properties of graphite particles as revealed from X-ray diffraction, Raman spectroscopy and TEM measurements. These modifications allow to enhance the electrochemical performances as anode materials in Li-ion battery.

\section{Experimental Section}

Raw material was natural graphite powder samples (called "raw") with average particles diameter of $7 \mu \mathrm{m}$. Surface fluorination was performed from 200 to $400{ }^{\circ} \mathrm{C}$ by elemental fluorine (purity: 99.4-99.7\%) in a nickel reactor of $3 \times 10^{4}$ Pa for $2 \mathrm{~min}$.

Transmission electron images were obtained with a Jeol JEM 100 CX II transmission electron microscope equipped with a Jeol high resolution scanning attachment (STEMSEM ASID 4D). The structural characterization of the samples was performed by X-ray diffraction using a Siemens D5000 X-Ray diffractometer with a $\mathrm{CuK} \alpha$ radiation $\left(\lambda_{1}=1.54178 \AA\right)$ and a nickel filter. The Raman spectra were recorded at room temperature using a micro-Raman system with a Dilor XY spectrometer equipped with a charge coupled device (CCD) detector. An argon ion laser $(514.5 \mathrm{~nm})$ was employed as the excitation source. A 50X objective was used to focus the laser light on sample surface to a spot of $5 \mu \mathrm{m}^{2}$ and the laser power was kept to $1 \mathrm{~mW}$ to avoid any degradation of the film. Finally, the spectra were measured in back-scattering geometry.

The electrochemical lithium insertion/deinsertion reaction was studied at room temperature in a glove box in $1 M \mathrm{LiClO}_{4}$-EC:DEC $(1: 1)$ solution. Counter and reference electrodes were metallic lithium foils. All potential values will be referred to this $\mathrm{Li} / \mathrm{Li}^{+}$ reference henceforth. The galvanostatic charge-discharge was performed using a potentiostat/galvanostat (VMP Bio-Logic) in the potential range $0.02-2.5 \mathrm{~V}$ at a current 
density of $60 \mathrm{~mA} / \mathrm{g}$. Impedance measurements were performed using an Autolab frequency analyzer between $10^{6}$ and $10^{-3} \mathrm{~Hz}$.

\section{Results and Discussion}

\section{$\underline{\text { Structural characterization }}$}

One of our main objectives was to create defects on the surface of the particles in order to increase the Li storage. Among the physico-chemical available techniques, Raman spectroscopy provides fruitful information about the surface disordering. Graphitic carbons are strong Raman scatters in spite of their intense optical absorption. Because of the weak interlayer bonding, disorder along the c-axis can occur in the graphite crystal, while at the same time, the strong interlayer $\mathrm{C}-\mathrm{C}$ bonding maintains a high degree of order within the individual carbon sheets. Therefore, Raman spectra of carbon materials are usually characterized by a pair of bands at around $1580 \mathrm{~cm}^{-1}$ and $1360 \mathrm{~cm}^{-1}$, called G-band and D-band, respectively. The G-Band is assigned to the $\mathrm{E}_{2 \mathrm{~g}}{ }^{2}$ carbon-carbon stretching mode whereas the $\mathrm{D}$-band is due to the $\mathrm{A}_{1 \mathrm{~g}}$ vibration mode in the disordered region of carbon materials or edge plane of powdery carbon. The ratio, $\mathrm{R}$, of intensity of D-band, $I_{D}$, to that of G-band, $I_{G},\left(R=I_{D} / I_{G}\right)$ depends on the structure of the carbon and indicates the degree of disordering of the carbon surface.

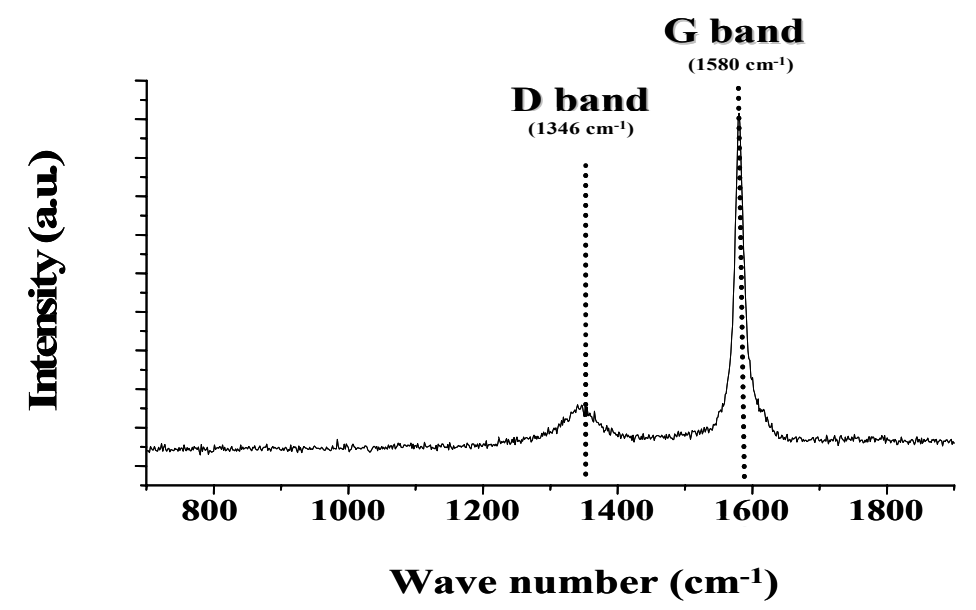

Figure 1. Raman spectrum obtained with graphite powder fluorinated with $\mathrm{F}_{2}$ at $200{ }^{\circ} \mathrm{C}$.

In the case of raw graphite powders, low $\mathrm{R}$ value of 0.07 was obtained. Fig. 1 shows the Raman spectrum of graphite powders heat-treated at $300{ }^{\circ} \mathrm{C}$ under $F_{2}$ atmosphere. The $\mathrm{G}$ and D-bands are observed at 1580 and $1346 \mathrm{~cm}^{-1}$. The highest D-band intensity was observed for graphite powders fluorinated at $400{ }^{\circ} \mathrm{C}$, giving rise to the highest $\mathrm{R}$ values: $\mathrm{R}=0.11,0.29$ and 0.69 for $\mathrm{T}_{\mathrm{F}_{2}}=200,300$ and $400{ }^{\circ} \mathrm{C}$, respectively. These values are higher than the one obtained in the case of raw graphite $(\mathrm{R}=0.07)$. As expected, the fluorination of graphite powders during short time gives rise to the formation of surface defects.

The XRD patterns of raw and fluorinated carbonaceous materials does not reveal any significant difference. The XRD pattern obtained with graphite fluorinated at $200{ }^{\circ} \mathrm{C}$ is presented in Fig. 2a. Whatever the fluorination temperature, the XRD patterns revealed the presence of well-defined peaks at around $2 \theta \approx 26.5,42.3,44.5$ and $54.6^{\circ}$ due to the (002), (100), (101) and (004) diffraction lines of graphite, respectively. One must notice the presence of a non-identified peak at $2 \theta \approx 43.3^{\circ}$ (insert of Fig. $2 a$ ) in the raw and the 
fluorinated graphite powders probably due to impurity. The interlayer distance, $\mathrm{d}_{002}$, was deduced from the relation of Bragg and the position of the (002) diffraction line. The evolution of the intensity of the (002) diffraction lines $v s . \mathrm{T}_{\mathrm{F}_{2}}$ is given in Fig. $2 \mathrm{~b}$. The decrease of the intensity for increasing fluorination temperature is a clear indication of the decrease of the crystallinity of the starting materials $v s$. increasing temperature. In the case of raw graphite, the $\mathrm{d}_{002}(0.3360 \pm 0.006 \mathrm{~nm})$ is closed to the theoretical one $(0.3354$ $\mathrm{nm})$. After fluorination, the $\mathrm{d}_{002}$ values does not vary for $\mathrm{T}_{\mathrm{F}_{2}}=200$ and $300{ }^{\circ} \mathrm{C}: \mathrm{d}_{002}=$ $0.3366 \pm 0.006 \mathrm{~nm}$. However, an significant increase was observed for $\mathrm{T}_{\mathrm{F}_{2}}=400{ }^{\circ} \mathrm{C}$, indicating an increase of the interlayer graphene layer. These experiments have revealed that even if solid fluorocarbons are present on the surface as pointed out by TEM measurements, their presence into the bulk is too low to be detected (content less than $1 \%)$.
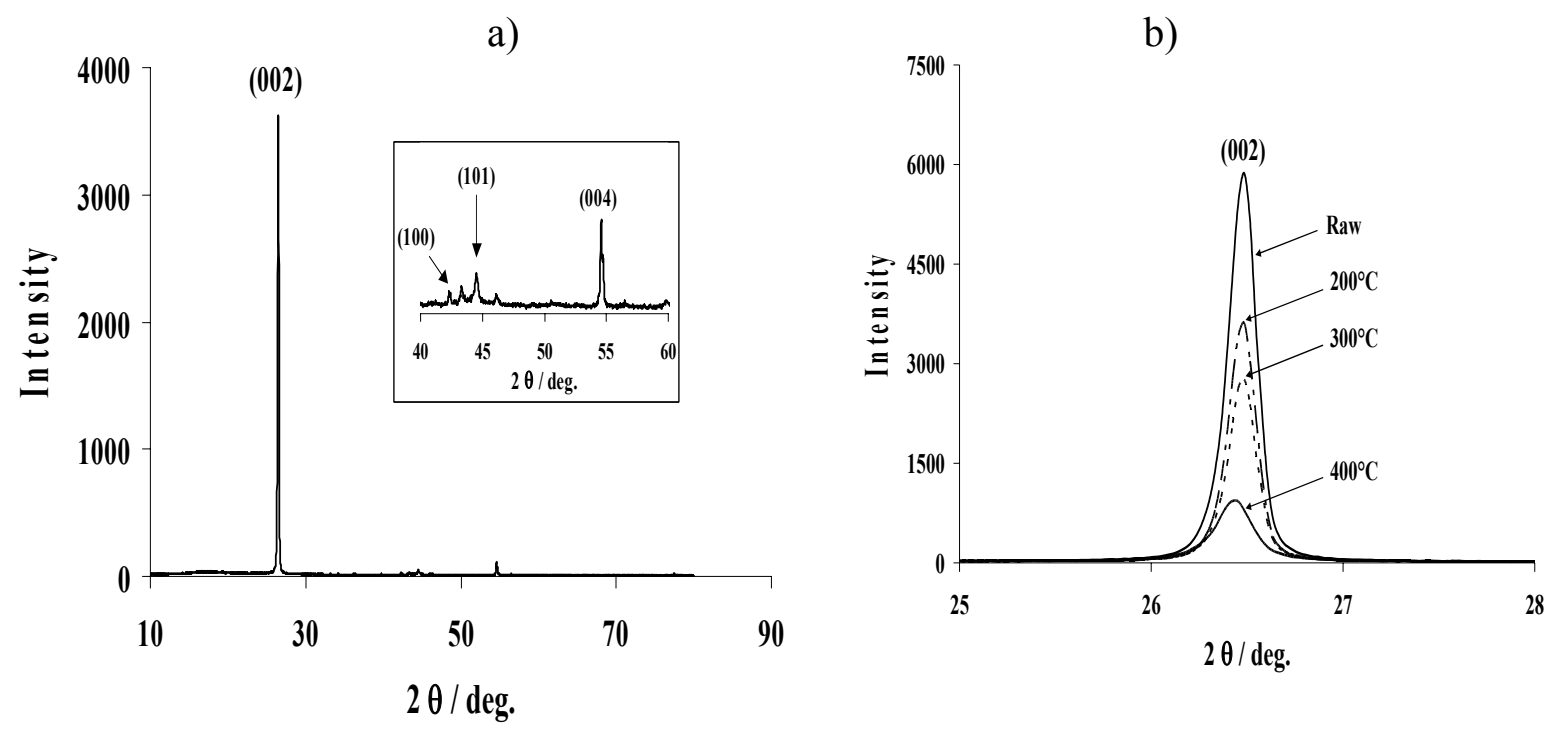

Figure 2. a) XRD pattern of graphite fluorinated under $F_{2}$ atmosphere at $200^{\circ} \mathrm{C}$. b) Expanded view of the (002) diffraction line region depending on the fluorination temperature.

TABLE I. Influence of the temperature of the fluorination treatment using $\mathrm{F}_{2}$ on the interlayer distance, $\mathrm{d}_{002}$, and the coherent length of the graphite crystallites $\mathrm{L}_{\mathrm{c}}$ and $\mathrm{L}_{\mathrm{a}}$.

\begin{tabular}{lccc}
\hline $\left.\mathbf{T}_{\mathbf{F}_{\mathbf{2}}} \mathbf{(}{ }^{\mathbf{0}} \mathbf{C}\right)$ & $\mathbf{d}_{\mathbf{0 0 2}}(\mathbf{n m})$ & $\mathbf{L}_{\mathbf{c}}(\mathbf{n m})$ & $\mathbf{L}_{\mathbf{a}}(\mathbf{n m})$ \\
\hline Raw & 0.3360 & 69 & 59 \\
200 & 0.3366 & 74 & 63 \\
300 & 0.3366 & 68 & 64 \\
400 & 0.3371 & 45 & 74 \\
\hline
\end{tabular}

The coherent length of the graphite crystallites along the c-axis, $\mathrm{L}_{\mathrm{c}}$, and the a-axis, $\mathrm{L}_{\mathrm{a}}$, were deduced from the broadening of the (002) and (001) peaks, respectively, and considering the classical Scherrer's equation. Note that for this determination, the angular full width at half maximum intensity of the corresponding $(h k l)$ diffraction lines was corrected from the instrumental line broadening $\left(0.05^{\circ}\right)$. Concerning the evolution of the $\mathrm{L}_{\mathrm{c}}$ values vs. $\mathrm{T}_{\mathrm{F}_{2}}$ (Table I), rather no variation was observed until $300{ }^{\circ} \mathrm{C}$. By contrast, a significant decrease of $\mathrm{L}_{\mathrm{c}}$ from about $70 \pm 3 \mathrm{~nm}$ to $45 \pm 3 \mathrm{~nm}$ was pointed out when the 
temperature of the fluorination procedure increases from 300 to $400{ }^{\circ} \mathrm{C}$, respectively. This evolution could be explained by the fact that the insertion of fluorine between the graphene layers coupled with heat-treatment induces: (i) exfoliation of the graphitic lattice, (ii) partial disintegration of carbon particles: some of them could be eliminated as fluorocarbon gases such as $\mathrm{CF}_{4}$. Concerning the evolution of the $\mathrm{L}_{\mathrm{a}}$ values vs $\mathrm{T}_{\mathrm{F}_{2}}$ (Table I), the intensity of the (001) diffraction line is too small to give accurate values.

a)

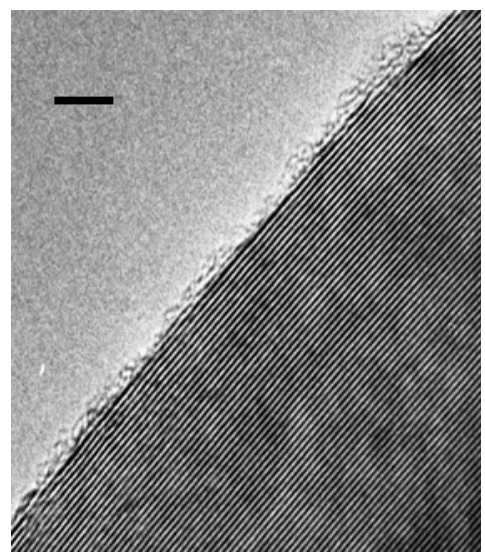

b)

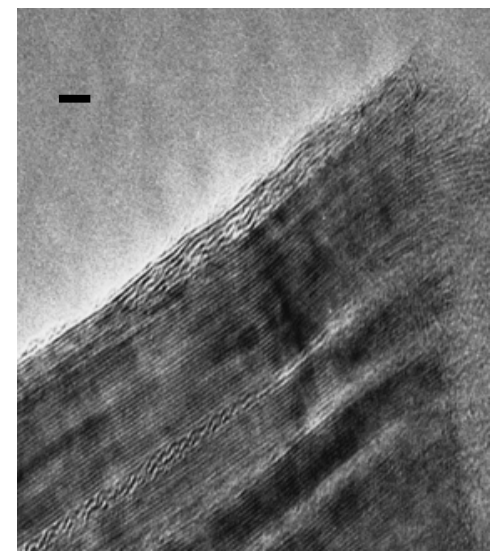

c)

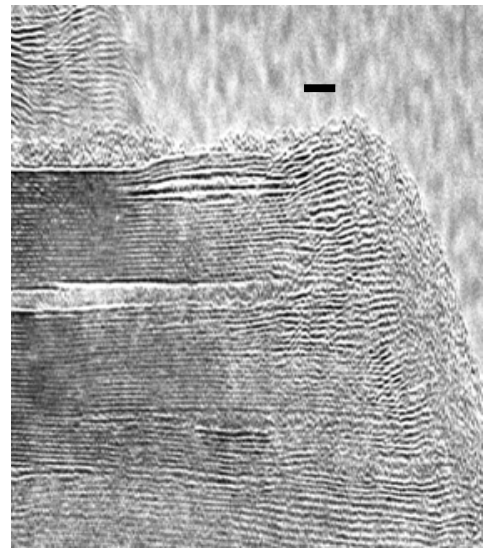

Figure 3. TEM images of graphite fluorinated with $\mathrm{F}_{2}$. a) 200 , b) 300 , and c) $400{ }^{\circ} \mathrm{C}$. Bar scale: $10 \mathrm{~nm}$.

Finally, TEM observations were performed with raw and fluorinated samples. Figure 3 gives the TEM images of graphite fluorinated with $\mathrm{F}_{2}$ for increasing temperature. At $\mathrm{T}_{\mathrm{F}_{2}}=200{ }^{\circ} \mathrm{C}$ (Fig. 3a), the fluorinated graphite exhibits surface disordered structure by contrast with the raw graphene layers. Nevertheless, only the surface of the particles was affected by the fluorination process and the thickness which is modified is about 3 $\mathrm{nm}$ (Fig. 3b). No modification of the bulk was observed. The fringe spacing deduced form Fig. 3a (about $0.34 \mathrm{~nm}$ ) is very similar to the theoretical distance between adjacent graphene sheets, $\mathrm{d}_{002}$, deduced from XRD analyses (Table I). For $\mathrm{T}_{\mathrm{F}_{2}}=300{ }^{\circ} \mathrm{C}$, the surface was modified on a larger thickness of about $10 \mathrm{~nm}$. The insertion of fluorine gas occurred at the edge of the particles as shown in Fig. 3b, inducing bulk modifications. For $\mathrm{T}_{\mathrm{F}_{2}}=400{ }^{\circ} \mathrm{C}$ (Fig. 3c), important changes have been observed: disordered fluorinated layers were generated at the edge of the graphite particles. A drastic modification of the bulk was also observed. These TEM investigations are in good agreement with results deduced from Raman spectroscopy and X-ray diffraction concerning the increase of the surface disordering and bulk modification, respectively, with increasing fluorination temperature.

\section{Electrochemical performances}

The influence of the fluorination of graphite powders for different temperature on the lithium insertion/de-insertion process was investigated by chronopotentiometry and impedancemetry. Raw and fluorinated graphite were used as negative electrode. For $\mathrm{T}_{\mathrm{F}_{2}}=200$ and $300{ }^{\circ} \mathrm{C}$, no difference was observed for the shape of curves between the raw and the fluorinated samples. The chronopotentiogram obtained for graphite powder fluorinated at $200{ }^{\circ} \mathrm{C}$ is presented in Fig. 4. 
By contrast, for $\mathrm{T}_{\mathrm{F}_{2}}=400^{\circ} \mathrm{C}$, a small potential plateau was observed around $2.5 \mathrm{~V} v \mathrm{~s}$. $\mathrm{Li}^{0} / \mathrm{Li}^{+}$(not shown) which can be attributed to the reduction of small amount of graphite fluorides having covalent $\mathrm{C}-\mathrm{F}$ bonds as reported above. The formation of the SEI layer gives rise to a small plateau at around $0.7 \mathrm{~V} v s . \mathrm{Li} / \mathrm{Li}^{+}$. An expanded view of the voltage profiles between $0.4 \mathrm{~V}$ and $0.02 \mathrm{~V}$ is presented in the inset of Fig. 4. This profile exhibits three plateaus at $0.20 \mathrm{~V}, 0.10 \mathrm{~V}$ and $0.07 \mathrm{~V} v s . \mathrm{Li}^{0} / \mathrm{Li}^{+}$. These potentials have been assigned to the coexistence of two-phase regions caused by the stage transformations between diluted stage $1 \leftrightarrow$ stage 4 , stage $2 \mathrm{~L} \leftrightarrow$ stage 2 and stage $2 \leftrightarrow$ stage 1 transitions, respectively, of lithium-GIC $(1-3,7,10,12)$.

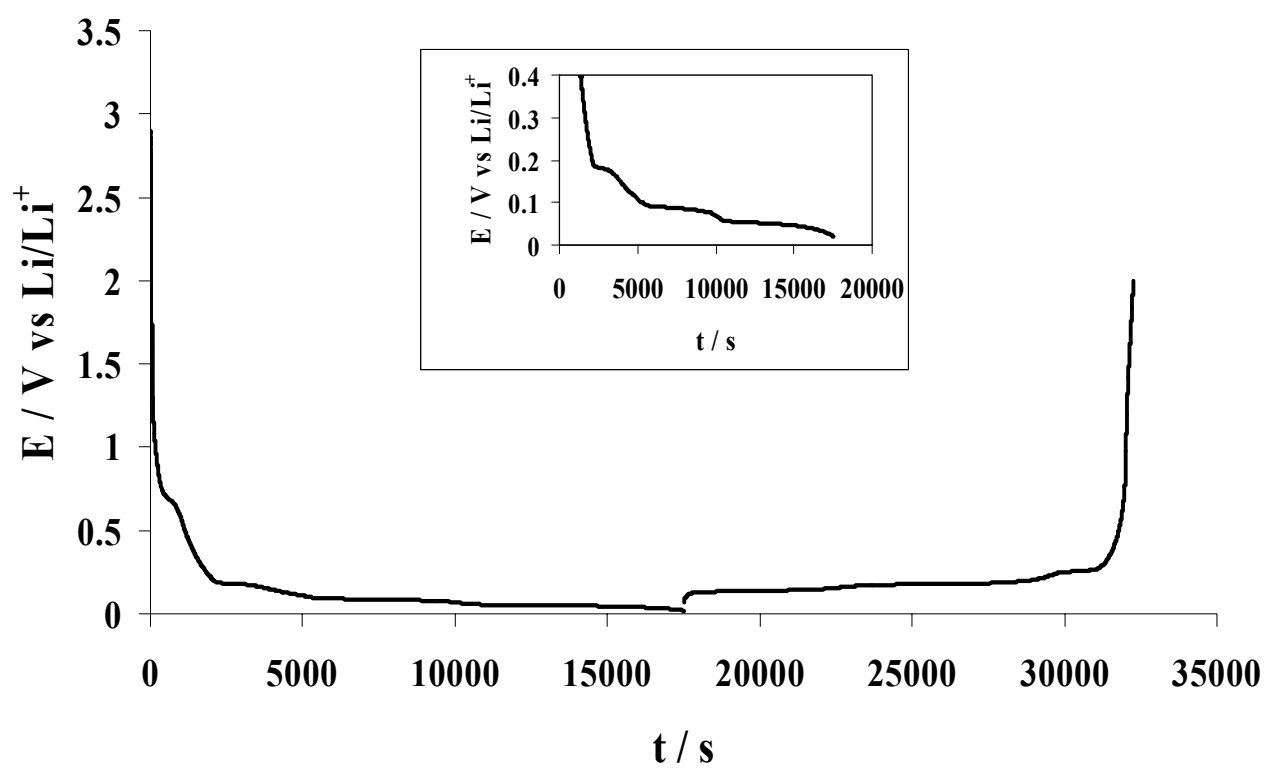

Figure 4. Typical first charge/discharge curves in galvanostatic mode obtained in $1 \mathrm{M}$ $\mathrm{LiClO}_{4}$-EC:DEC (1:1) with graphite powders fluorinated at $200{ }^{\circ} \mathrm{C}$ with $\mathrm{F}_{2}$. An expand view between $0.4-0 \mathrm{~V} v s . \mathrm{Li}^{0} / \mathrm{Li}^{+}$is given in the inset of the figure.

The variation of the reversible capacity, $\mathrm{Q}_{\text {rev., }} v s$. fluorination temperature after 15 charge/discharge cycles is given in Fig. 5. The fluorination until $300{ }^{\circ} \mathrm{C}$ leads to a significant increase of the capacity retention of Li into the host structure. Thus, the $\mathrm{Q}_{\text {rev. }}$ value for $\mathrm{T}_{\mathrm{F}_{2}}=300{ }^{\circ} \mathrm{C}(380 \mathrm{mAh} / \mathrm{g})$ is slightly higher than the theoretical one $(372 \mathrm{mAh} / \mathrm{g})$ and larger than the experimental one obtained with the raw materials $(\approx$ $340 \mathrm{mAh} / \mathrm{g}$ ). To explain such a behavior, one may suggest that this high values may originate from the insertion of lithium not only between organized graphene layers but also into regions without organized graphitic structure (13). In addition, it was shown that the surface areas of graphite powders measured by BET method is increased by fluorination of the materials during a small time due to partial $\mathrm{C}-\mathrm{C}$ bond breaking $(6,9$, 44). Consequently, a larger amount of lithium can be stored in fluorinated graphite.

Finally, impedance measurements were performed at the end of the delithiation (i.e. after re-oxidation) to get electric information on the SEI layer. The typical Nysquist diagram obtained for $\mathrm{T}_{\mathrm{F}_{2}}=200^{\circ} \mathrm{C}$ is presented in Fig. 6 .

The first part of the diagram (between $10^{5} \mathrm{~Hz}$ and $26.5 \mathrm{~Hz}$ ) is related to the SEI layer. The diameter of this semi-circle is equal to the resistance of the SEI layer, denoted $\mathrm{R}_{\mathrm{SEI}}(2$, $10,48,49)$. The second phenomenon, which gives rise to a second semi-circle between 
$26.5 \mathrm{~Hz}$ and $0.28 \mathrm{~Hz}$, is related to the charge transfer. The charge transfer resistance, $\mathrm{R}_{\mathrm{ct}}$, is equal to the diameter of this second semi-circle. Finally, in low frequency region (between 0.28 to $4 \mathrm{mHz}$ ), the Warburg contribution is considered. For the latter, a straight line showing a $45^{\circ}$ angle against the real axis is usually obtained. Nevertheless, as mentioned above, the impedance spectrum presented in Fig. 6 was obtained after complete extraction of lithium from the graphite lattice; it explains why a straight line with a slope of $90^{\circ}$ is observed at low frequency instead of $45^{\circ}$. The values deduced from the fitting of the curves are given in Table II.

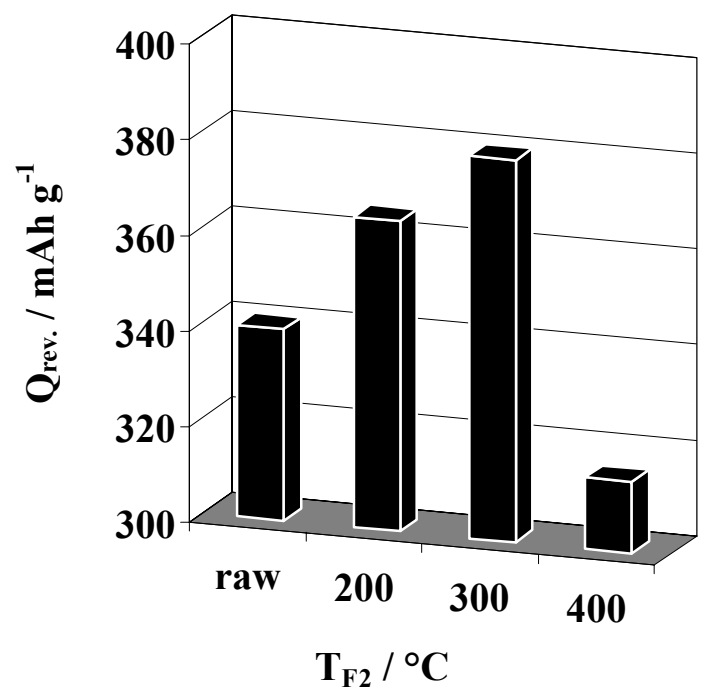

Figure 5. Comparison of the reversible capacity after 15 charge/discharge cycles at $\pm 60 \mathrm{~mA} / \mathrm{g}$ in $1 \mathrm{M} \mathrm{LiClO}_{4}$-EC:DEC (1:1) obtained with raw and fluorinated graphite powders.

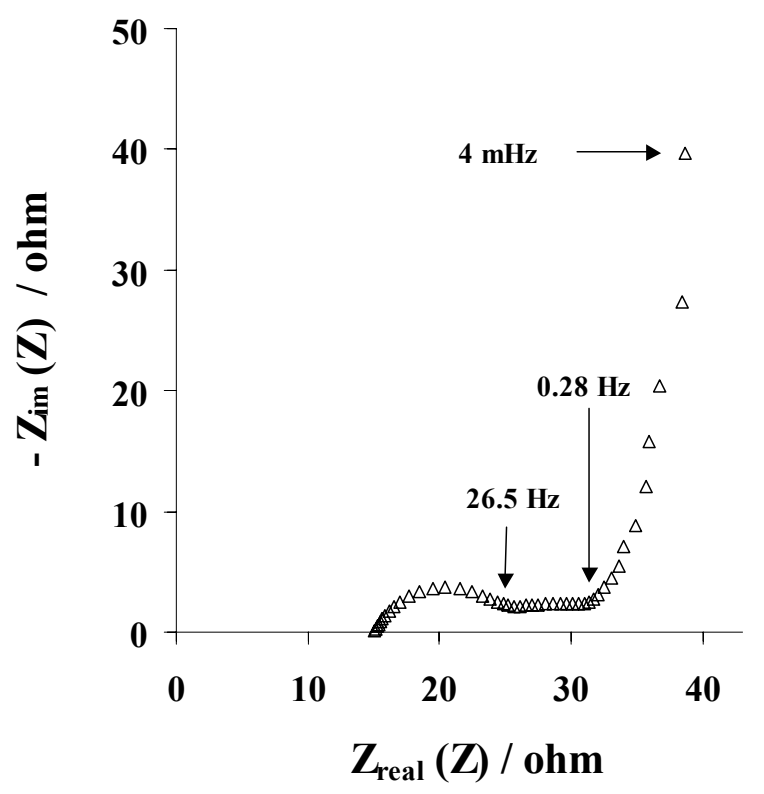

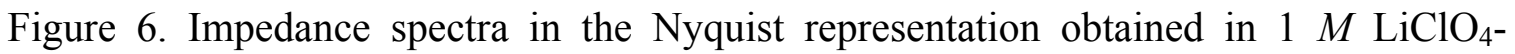
EC:DEC (1:1) with fluorinated-graphite anode $\left(\mathrm{T}_{\mathrm{F}_{2}}=200^{\circ} \mathrm{C}\right)$ after complete delithiation. 
As shown in Table II, both the resistances related to the SEI and to the charge transfer were lower for the samples fluorinated at $\mathrm{T}_{\mathrm{F}_{2}} \leq 300^{\circ} \mathrm{C}: \mathrm{R}_{\mathrm{SEI}} \approx 15 \Omega$ and $\mathrm{R}_{\mathrm{ct}} \approx 19 \Omega$ for $\mathrm{T}_{\mathrm{F}_{2}}=200{ }^{\circ} \mathrm{C}$ and $\mathrm{R}_{\mathrm{SEI}} \approx 5.5 \Omega$ and $\mathrm{R}_{\mathrm{ct}} \approx 8 \Omega$ for $\mathrm{T}_{\mathrm{F}_{2}}=300^{\circ} \mathrm{C}$.

Table II. Data deduce from the fitting of impedance spectra obtained in $1 \mathrm{M} \mathrm{LiClO}_{4}$ EC:DEC (1:1) with raw and fluorinated-graphite anode after complete delithiation.

\begin{tabular}{lcc}
\hline $\mathbf{T}_{\mathbf{F}_{\mathbf{2}}}\left({ }^{\mathbf{0}} \mathbf{C}\right)$ & $\mathbf{R}_{\mathbf{S E I}}(\boldsymbol{\Omega})$ & $\mathbf{R}_{\mathbf{c t}}(\boldsymbol{\Omega})$ \\
\hline Raw & 15 & 19 \\
200 & 8.7 & 12 \\
300 & 5.5 & 8 \\
400 & 17.7 & 23.1 \\
\hline
\end{tabular}

On the contrary, higher values were observed for $\mathrm{T}_{\mathrm{F}_{2}}=400{ }^{\circ} \mathrm{C}$, in good agreement with conclusions deduced from the investigations by chronopotentiometry. These results mean that for $\mathrm{T}_{\mathrm{F}_{2}} \leq 300^{\circ} \mathrm{C}$, the charge transfer at the fluorinated graphite interface is faster than that observed in the case of pure graphite. The reduction of the resistance of the SEI could result from a strong modification of the composition of the layer and/or a decrease of its thickness due to the present of small amount of surface C-F bonds. Consequently, the total cell resistance is decreased by using surface-fluorinated graphite powders. The increase of the reversible capacities observed from the analysis of chronopotentiograms is here clearly understood.

\section{Acknowledgments}

The authors would like to thank M. M. Selmane (P. \& M. Curie University - INSP, Paris) for helpful assistance in XRD characterizations. This work was done within the frame of an international scientific program called «Materials for the 21st century - Materials Development for Environment, Energy and Information" financially supported by the Japanese Ministry of Education.

\section{References}

1. J. R. Dahn, Phys. Rev. B 44, 9170 (1991).

2. T. Ohzuku, Y. Iwakoshi, K. Sawai, J. Electrochem. Soc. 140, 2490 (1993).

3. D. Aurbach, in Nonaqueous Electrochemistry, D. Aurbach, Editor, Chap. 6, pp. 289409, Marcel Dekker, New York (1999).

4. B. Simon, S. Flandrois, K. Guérin, A. Février-Bouvier, I. Teulat, P. Biensan, J. Power Sources 81-82, 312 (1999).

5. R. Yazami, Electrochim. Acta 45, 87 (1999).

6. T. Nakajima, K. Dan, M. Koh, J. Fluorine Chem. 87, 221 (1998).

7. S. Flandrois, B. Simon, Carbon 37, 165 (1999).

8. H. Groult, B. Kaplan, F. Lantelme, T. Nakajima, V. Gupta, S. Komaba, N. Kumagai, B. Simon, J. Electrochem. Soc. 150, G67 (2003).

9. T. Nakajima, V. Gupta, Y. Ohzawa, H. Iwata, A. Tressaud, E. Durand, J. Fluorine Chem. 114, 209 (2002).

10. Z. Ogumi, M. Inaba, Bull. Chem. Soc. Jpn. 71, 521 (1998).

11. J. R. Dahn, Phys. Rev. B 44, 9170 (1991). 
12. A. Funabiki, M. Inaba, T. Abe, Z. Ogumi, J. Electrochem. Soc. 146, 2443 (1999).

13. H. Groult, B. Kaplan, F. Lantelme, S. Komaba, N. Kumagai, H. Yashiro, T. Nakajima, B. Simon, A. Barhoun, Solid States Ionics 177869 (2006).

14. J. S. Xue and J. R. Dahn, J. Electrochem. Soc., 142, 3668 (1995).

15. E. Peled, C. Menachem, D. Bar-Tow and A. Melman, J. Electrochem. Soc., 143, L4 (1996).

16. M. Hara, A. Satoh, N. Tamaki and T. Ohsaki, Tanso, 165, 261 (1994).

17. S. Shiraishi, K. Kanamura, Z. Takehara, J. Electrochem. Soc. 146, 1633 (1999).

18. D. Aurbach, Y. Ein-Eli, B. Markovsky, A. Zaban, S. Luski, Y. Carmeli, H. Yamin, J. Electrochem. Soc. 142, 2882 (1995).

19. T. Osaka, T. Momma, T. Tajima, Y. Matsumoto, J. Electrochem. Soc. 142, 1057 (1995).

20. D. Aurbach, K. Gamolsky, B. Markovsky, Y. Gofer, M. Schmidt, U. Heider, Electrochim. Acta 47, 1423 (2002).

21. S. Komaba, T. Itabashi, B. Kaplan, H. Groult, N. Kumagai, J. Power Sources 146, 166 (2005).

22. R. Takagi, T. Okubo, K. Sekine and T. Takamura, Denki Kagaku, 65, 333 (1997).

23. S.-S. Kim, Y. Kadoma, H. Ikuta, Y. Uchimoto and M. Wakihara, Electrochem. SolidState Lett., 4, A109 (2001).

24. I. R.M. Kottegoda, Y. Kadoma, H. Ikuta, Y. Uchimoto and M. Wakihara, Electrochem. Solid-State Lett., 5, A275 (2002).

25. I. R. M. Kottegoda, Y. Kadoma, H. Ikuta, Y. Uchimoto and M. Wakihara, J. Electrochem. Soc., 152, A1595 (2005).

26. M. Yoshio, H. Wang, K. Fukuda, Y. Hara and Y. Adachi, J. Electrochem. Soc., 147, $1245(2000)$.

27. H. Wang, M. Yoshio, T. Abe and Z. Ogumi, J. Electrochem. Soc., 149, A499 (2002).

28. M. Yoshio, H. Wang, K. Fukuda, T. Umeno, N. Dimov and Z. Ogumi, J. Electrochem. Soc. 149, A1598 (2002).

29. Y.-S. Han and J.-Y. Lee, Electrochim. Acta, 48, 1073 (2003).

30. Y. Ohzawa, M. Mitani, T. Suzuki, V. Gupta and T. Nakajima, J. Power Sources, 122, 153 (2003).

31. Y. Ohzawa, Y. Yamanaka, K. Naga and T. Nakajima, J. Power Sources, 146, 125 (2005).

32. H. Groult, C. Simon, A. Mantoux, F. Lantelme, P. Turq, Fluorinated Materials for Energy Conversion, T. Nakajima and H. Groult, Editors, Chap. 1, pp. 1-29, Elsevier, Amsterdam (2005).

33. T. Nakajima, V. Gupta, Y. Ohzawa, M. Koh, R.N. Singh, A. Tressaud, E. Durand, J. Power Sources 104, 108 (2002).

34. N. Watanabe, T. Nakajima, H. Touhara, Graphite Fluorides, Vol. 8, Elsevier, Amsterdam (1988).

35. H. Touhara, Fluorinated Materials for Energy Conversion, T. Nakajima and H. Groult, Editors, Chap. 4, pp. 89-102, Elsevier, Amsterdam (2005).

36. T. Nakajima, N. Watanabe, Graphite fluorides, Carbon-Fluorine Compounds, CCR Press, Boca Raton (1991).

37. A. Tressaud, C. Guimon, V. Gupta, F. Moguet, Mater. Sci. Eng. B 30, 61 (1995).

38. G. Nansé, E. Papirer, P. Fioux, F. Moguet, A. Tressaud, Carbon 35, 175 (1997).

39. A. Hamwi, M. Daoud, J.C. Cousseins, Synth. Metals 30, 23 (1989).

40. R. Yazami, P. Hany, P. Masset, A. Hamwi, Mol. Cryst. Liq. Cryst. 310, 39 (1998).

41. T. Nakajima, H. Touhara, F. Okino, l'Actualité Chimique 301-302, 119 (2006) 
42. T. Nakajima, M. Koh, R.N. Singh and M. Shimada, Electrochim. Acta, 44, 2879 (1999).

43. V. Gupta, T. Nakajima, Y. Ohzawa and H. Iwata, J. Fluorine Chem., 112, 233 (2001). 44. H.Groult, T. Nakajima, L. Perrigaud, Y. Ohzawa, H. Yashiro, S. Komaba, N. Kumagai, J. Fluorine Chem. 126, 1111 (2005).

45. T. Nakajima, J. Li, K. Naga, K. Yoneshima, T. Nakai and Y. Ohzawa, J. Power Sources, 133, 243 (2004).

46. J. Li, K. Naga, Y. Ohzawa, T. Nakajima, A. P. Shames and A. I. Panich, J. Fluorine Chem., 126, 265 (2005).

47. J. Li, Y. Ohzawa, T. Nakajima and H. Iwata, J. Fluorine Chem., 126, 1028 (2005).

48. W. Weppner, R.A. Huggins, J. Solid States Chem. 22, 297 (1977)

49. M. Holzapfel, A. Martinent, F. Alloin, B. Le Gorrec, R. Yazami, C. Montella, J. Electroanal. Chem. 546, 41 (2003). 